\title{
LABORATORY GERMINABILITY AND GERMINATION ENERGY OF SPELT GRAIN DEPENDING ON FERTILIZATION AND STORAGE
}

Liubych V.V., Zhelezna V.V., Kostetska K.V. Uman National University of Horticulture

The article presents the results of studying the germinability and germination energy of spelt grain depending on fertilization and storage duration. The pre-storage germination energy of spelt grain was found to be $87-90 \%$, depending on nitrogen fertilizer types, doses and application time. After 30- or 90-day storage, the germination energy was the highest, amounting to $98-99 \%$. Further storage decreased this indicator. The greatest effect was exerted by single application of $120 \mathrm{~kg} / \mathrm{ha}$ of nitrogen fertilizers once in spring.

Key words: spelt, germinability, germination energy, fertilization, storage.

Introduction. Spelt is a promising crop for processing, as valuable micronutrients are evenly distributed in its grain, while in modern wheat bread varieties they are concentrated in the hull, aleurone layer and germ. Its proteins contain more gliadins and fewer glutenins, making gluten weak, but better digestible in the human body. Currently, this crop is insufficiently studied, therefore, studies of germinability and germination energy of spelt depending on fertilization and shelf life are relevant and practically feasible [1-3].

Literature review and problem articulation. In modern agriculture, high-quality seeds are of paramount importance as a means of production. High-quality seeds are one of the main prerequisites for achieving high yields [4]. The germination energy is the ability of seeds to germinate quickly and simultaneously. It is defined as a conventionally accepted period, which is almost twice as short as for the laboratory germinability determination and is calculated as the number of normally germinated seeds expressed as a percentage [5]. Some researchers consider the germination energy as the main indicator of the biological value of seeds. Plants grown from seeds with high germination energy show better performance and are more resistant to adverse environmental factors. The germination energy can be considered a qualitative indicator of the seed viability $[6,7]$.

The germinability is the ability of seeds to form normally developed seedlings. This indicator is expressed as a percentage of the total number of seeds taken for germination. Studies identified different factors affecting the germination and germinability of seeds. They can be grouped into biological (biotic) and abiotic ones. Knowledge of these factors allows for effective control and management of the germinability of seeds $[8,9]$.

Grain storage is one of the most important stages that determine the grain quality during processing and the quality of seeds intended for sowing. It can have both a positive effect as a result of post-harvest ripening and negative consequences, leading, under the influence of different factors, to grain deterioration. The temperature of grain mass is a particularly important indicator characterizing the grain mass condition during storage $[10,11]$. Ukraine has not developed specific storage conditions for spelt grain. In this case, conventional conditions of wheat grain storage are adhered to (State Standard of Ukraine DSTU 3768: 2019). The quality of both bread wheat and spelt grain also depends on the storage period. Changes in grain during storage depend both on raw material quality and on storage conditions. Given that spelt grain contains more protein $(25 \%)$ and gluten (up to $50 \%$ ) than grain of traditional wheat bread varieties, it is necessary to develop appropriate storage conditions for freshly harvested grains lest the grain mass change its quality. High humidity, inadequate temperature or air access in the granary provoke the spread of microorganisms causing diseases of the grain mass $[12,13]$.

(C) V.V. Liubych, V.V. Zhelezna, K.V. Kostetska. 2021.

ISSN 1026-9959. Селекція і насінництво. 2021. Випуск 119 
Fertilization is one of the most important measures in growing wheat technologies to increase yields and grain quality [14]. Spelt, as a high-protein crop, responds well to nitrogen fertilizers. The top grain quality is ensured by $\mathrm{N}_{30}$ application in spring, $\mathrm{N}_{30}$ application at the beginning of leaf-tube formation and $\mathrm{N}_{30}$ foliar application during the in milky ripeness phase in combination with $\mathrm{P}_{60} \mathrm{~K}_{60}$ [15]. Other scientists showed [16] that the effect of single application of nitrogen fertilizers on grain quality was similar to that of divided application. Depending on fertilizer, spelt can have a 1000-grain weight of 32.5-44.4 g, test weight of $725-739 \mathrm{~g} / \mathrm{L}$ and vitreousness of $77.0-83.0 \%$.

Purpose and objectives: to assess the germinability and germination energy of spelt depending on the types, doses and timing of nitrogen fertilization and storage period.

Materials and methods. The experimental site was located in Mankiv natural agricultural area of the Middle Dnipro-Bug Region of the Right-Bank Forest-Steppe (geographical coordinates at $48^{\circ} 46^{\prime} 56.47^{\prime \prime}$ north latitude and $30^{\circ} 14^{\prime} 48.51^{\prime \prime}$ east longitude). The altitude above the sea level was $245 \mathrm{~m}$. The soil in the experimental field was podzolic chernozem.

The study was conducted in 2014-2015. In general, the climate in this region is favorable for growing most of temperate crops. 2014 had sufficient precipitation. Thus, in April-July, the precipitation amount was $292 \mathrm{~mm}$, which was by $10 \%$ more than the multi-year average. However, this year was characterized by lower air and soil temperatures after renewal of vegetation in spring. The precipitation amount for the whole year was the lowest in $2015(520 \mathrm{~mm}$, which was 1.2 times less than the multi-year average $(633 \mathrm{~mm})$. In 2015, a significant amount precipitated during the spring-summer vegetation $(271 \mathrm{~mm})$, in April-July. Thus, the weather conditions during the study years were typical for the region. Fluctuations in precipitation, temperature and relative humidity during certain periods of spelt growing did not significantly affect its productive processes and quality.

The study was conducted in the Laboratory of Evaluation of Grain and Grain Product Quality of the Chair of Grain Storage and Processing Technologies of Uman National University of Horticulture. We studied winter spelt variety Yevropa created by hybridization of Triticum aestivum L. with T. spelta L. Spelt was fertilized, as Table 1 describes. In addition, the germinability and germination energy was assessed depending on the duration of grain storage. Fertilizers were ammonium nitrate, ammonium sulfate, granular superphosphate, and potassium chloride. The experimental plot area was $72 \mathrm{~m}^{2}$; the record area was $40 \mathrm{~m}^{2}$. The experiments were carried out in three replications. The plots were arranged inline. The forecrop was vetch-oat mixture grown for on green feed. The field experiments, observations and assessments were conducted by traditional methods.

Table 1

Experiment design

\begin{tabular}{|c|c|c|c|c|c|c|}
\hline \multirow{2}{*}{ Treatment } & \multirow{2}{*}{$\begin{array}{l}\text { Pre- } \\
\text { storage }\end{array}$} & \multicolumn{5}{|c|}{ Storage period, days } \\
\hline & & 30 & 90 & 180 & 270 & 360 \\
\hline No fertilizers (control) & + & + & + & + & + & + \\
\hline $\mathrm{P}_{60}+\mathrm{N}_{120}$ & + & + & + & + & + & + \\
\hline $\mathrm{K}_{60}+\mathrm{N}_{120}$ & + & + & + & + & + & + \\
\hline $\mathrm{P}_{60} \mathrm{~K}_{60}-$ basic fertilization & + & + & + & + & + & + \\
\hline Basic fertilization $+\mathrm{N}_{120}$ & + & + & + & + & + & + \\
\hline Basic fertilization $+\mathrm{N}_{60}+\mathrm{N}_{60}$ & + & + & + & + & + & + \\
\hline $\begin{array}{l}\text { Basic fertilization } \\
+\mathrm{N}_{60} \mathrm{~S}_{70}+\mathrm{N}_{60}\end{array}$ & + & + & + & + & + & + \\
\hline
\end{tabular}

Dry spelt grain (when packing for storage, water content was 13.0-13.5\%) was stored air tight sealed polyethylene tubings at unregulated temperature in a traditional depository. State Standard of Ukraine 4138-2002 "Seeds of Agricultural Crops. Methods of Quality Determination" does not specify analyses of spelt seeds. The International Seed Testing Association (ISTA) has issued requirements and methods for determining the sowing qualities of this crop [17]. It should be noted that the methods of analyzing the germinability and germination energy of bread wheat 
specified in DSTU 2240-93 coincide with the ISTA's corresponding methods for spelt. The germinability and germination energy were determined as percentages of the total number of seeds taken for germination (mean value, $n=4$ ). To determine these indicators, four samples of 100 seeds were taken in quick succession from a pure seed fraction and germinated in Petri dishes between filter paper sheets. Petri dishes were placed in thermostats at about $20^{\circ} \mathrm{C}$. The germination was monitored daily for 7 days. The germinability was expressed as the percentage of germinated seeds to the total number of seeds. After three and seven days of germination, the germination energy and laboratory germinability, respectively, were determined.

Result and discussion. The germination energy characterizes the viability of seeds, on which the germination rate depends. Seeds with high germination energy give early and uniform sprouts $[4,7]$. We found that the germination energy dynamics of spelt grain depended on the duration of storage and fertilization (Table 2, Fig. 1).

Table 2

Germination energy dynamics of spelt grain depending on fertilization and duration of storage (2014-2015), \%

\begin{tabular}{|c|c|c|c|c|c|c|}
\hline \multirow{2}{*}{ Treatment (A) } & \multirow{2}{*}{$\begin{array}{l}\text { Pre- } \\
\text { storage }\end{array}$} & \multicolumn{5}{|c|}{ Storage period, days (B) } \\
\hline & & 30 & 90 & 180 & 270 & 360 \\
\hline No fertilizers (control) & 87 & 99 & 98 & 96 & 92 & 88 \\
\hline $\mathrm{P}_{60}+\mathrm{N}_{120}$ & 89 & 99 & 99 & 98 & 95 & 90 \\
\hline $\mathrm{K}_{60}+\mathrm{N}_{120}$ & 89 & 99 & 99 & 98 & 95 & 90 \\
\hline $\mathrm{P}_{60} \mathrm{~K}_{60}-$ basic fertilization & 87 & 99 & 99 & 95 & 92 & 87 \\
\hline Basic fertilization $+\mathrm{N}_{120}$ & 90 & 99 & 99 & 98 & 95 & 90 \\
\hline $\begin{array}{l}\text { Basic fertilization }+\mathrm{N}_{60}+ \\
\mathrm{N}_{60}\end{array}$ & 89 & 98 & 99 & 98 & 95 & 90 \\
\hline $\begin{array}{l}\text { Basic fertilization } \\
+\mathrm{N}_{60} \mathrm{~S}_{70}+\mathrm{N}_{60}\end{array}$ & 89 & 99 & 99 & 98 & 96 & 91 \\
\hline$L D S_{05}$ & \multicolumn{6}{|c|}{$A=1, B=3, A B=4$} \\
\hline
\end{tabular}

Prior to storage, the germination energy was $87-90 \%$ depending on fertilizers, the maximum after $\mathrm{N}_{120}$ application. Nitrogen fertilizers significantly increased this indicator compared to not fertilized plots. The germination energy varied significantly depending on the duration of storage. After 30- and 90-day storage, the germination energy was the highest and amounted to 98-99\%. Further storage significantly decreased this parameter. After $\mathrm{P}_{60} \mathrm{~K}_{60}$ application, it was the lowest: $95 \%, 92 \%$ and $87 \%$ when seeds were storage for 180,270 and 360 days, respectively.

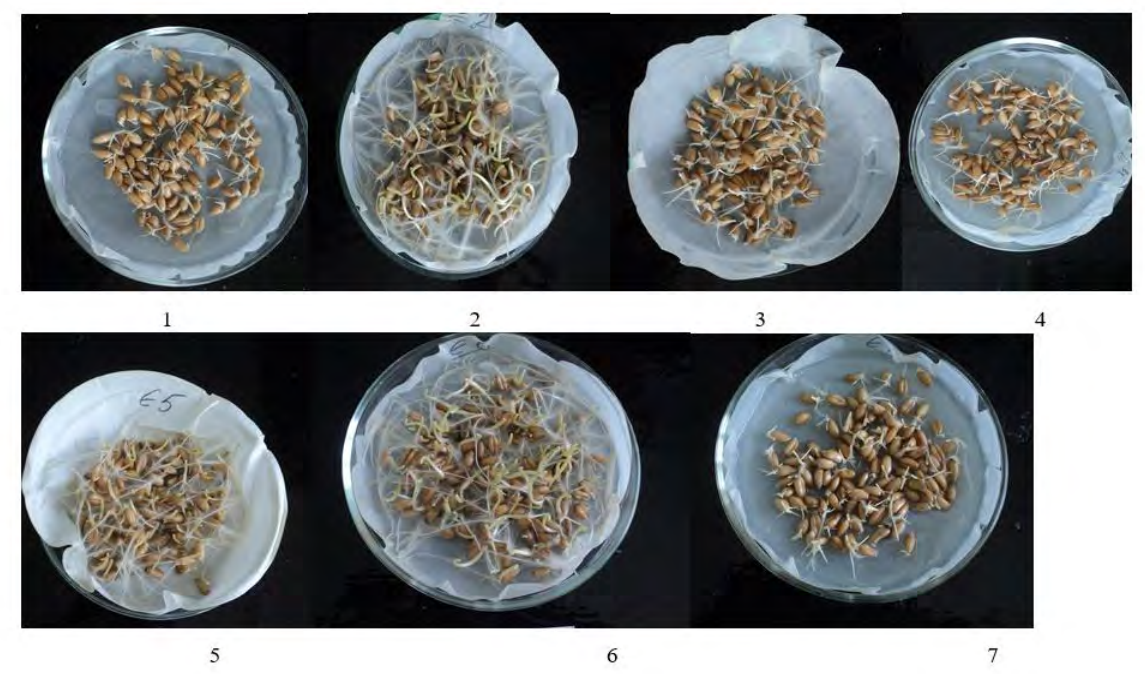

Fig. 1. The germination energy of spelt grain depending on fertilization 
1 - No fertilizers (control); $2-\mathrm{P}_{60}+\mathrm{N}_{120} ; 3-\mathrm{K}_{60}+\mathrm{N}_{120} ; 4-\mathrm{P}_{60} \mathrm{~K}_{60}-$ basic fertilization; 5 - basic fertilization $+\mathrm{N}_{120} ; 6$ - basic fertilization $+\mathrm{N}_{60}+\mathrm{N}_{60} ; 7$ - basic fertilization $+\mathrm{N}_{60} \mathrm{~S}_{70}+\mathrm{N}_{60}$.

Other reserchers [18] confirmed the effect of storage duration on the germination energy of seeds. They revealed that this indicator decreased after 1-year storage of grain. In a study [19], the germination energy of wheat grain varied significantly depending on the variety and duration of storage. This indicator was the lowest in the first two months of storage. Afterwards it grew to 85$95 \%$ depending on the winter wheat variety. After 1-year storage, this figure did not decrease, but was not significantly higher than that after 9-month storage.

The laboratory germinability is the most important indicator of seed quality; it largely depends on soil, climate, cultivation technology, and fertilization [7,9]. The sowing quality of seeds depends on their germinability. Appropriate standards are set for all field crops. The germinability of sseds determines the plant density and uniformity of stem distribution. The pre-storage laboratory germinability of spelt grain was found to be excellent regardless of fertilizers (Table 3, Fig. 2). Thus, before storage and after 30- and 90-day storage of spelt grain, this indicator was $99 \%$, and fertilizers did not change it. 180-day storage resulted in a decrease in the laboratory germinability by $1-2 \%$, depending on fertilization. After 270 -day storage, this parameter decreased to $88 \%$ in the control and $89 \%$ in the other experimental variants. The lowest laboratory germinability (81-84\%) was observed after 1-year storage, depending on fertilization, which was significant compared to the contral with $\mathrm{LSD}_{05}=3$. The maximum was recorded with $\mathrm{P}_{60}+\mathrm{N}_{120}$ and amounted to $84 \%$, while the lowest value was noticed without fertilizers or with $\mathrm{N}_{60} \mathrm{~S}_{70}+\mathrm{N}_{60}$.

Table 3

Laboratory germinability of spelt grain depending on fertilizers and duration of storage (2014-2015), \%

\begin{tabular}{lcccccc}
\hline \multirow{2}{*}{ Treatment } & \multirow{2}{*}{$\begin{array}{c}\text { Pre- } \\
\text { storage }\end{array}$} & \multicolumn{5}{c}{ Storage period, days } \\
\cline { 3 - 7 } & & 30 & 90 & 180 & 270 & 360 \\
\hline No fertilizers (control) & 99 & 99 & 99 & 97 & 88 & 81 \\
$\mathrm{P}_{60}+\mathrm{N}_{120}$ & 99 & 99 & 99 & 98 & 89 & 84 \\
$\mathrm{~K}_{60}+\mathrm{N}_{120}$ & 99 & 99 & 99 & 98 & 89 & 82 \\
$\mathrm{P}_{60} \mathrm{~K}_{60}-$ basic fertilization & 99 & 99 & 99 & 97 & 89 & 82 \\
${\text { Basic fertilization }+\mathrm{N}_{120}}_{\text {Basic fertilization }+\mathrm{N}_{60}+\mathrm{N}_{60}}$ & 99 & 99 & 99 & 98 & 89 & 83 \\
Basic fertilization & 99 & 99 & 99 & 98 & 89 & 82 \\
$+\mathrm{N}_{60} \mathrm{~S}_{70}+\mathrm{N}_{60}$ & 99 & 99 & 99 & 98 & 89 & 81 \\
\hline$L D S_{05}$ & \multicolumn{7}{c}{$A=1, B=3, A B=4$} \\
\hline
\end{tabular}

It is known [19] that during storage seeds are dormant and their vital activity almost ceases. However, they remain living organisms, and processes of physiological maturation, structural and biochemical reorganization still occur in themt. These processes can occur before harvesting on parentsl plants or during storage. It explains why the germination energy of spelt in the experiment immediatelty after harvest was lower compared to 30-day storage.

In the study [18], statistical analysis confirmed that the laboratory germinability of grain also strongly depended on the duration of its storage. The reserchers [19] noted that chromatin degeneration in the cell nucleus resulting in division arrest was the most frequent cause of a reduced sowing quality of grain. 


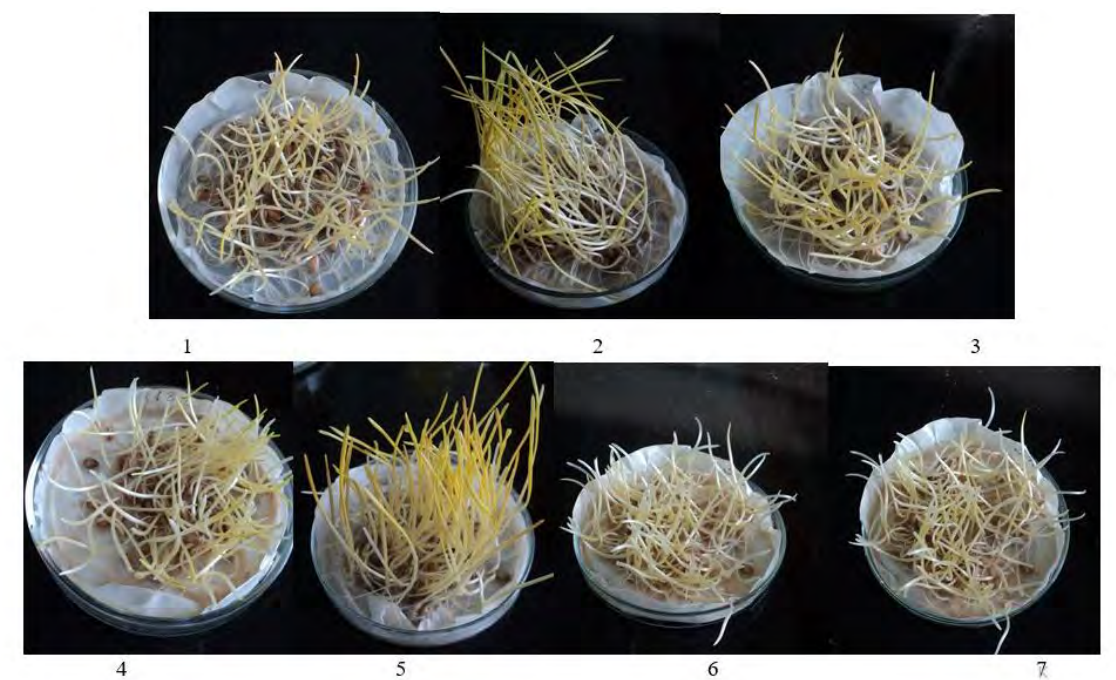

Fig. 2. Laboratory germinability of spelt grain depending on fertilization

1 - No fertilizers (control); $2-\mathrm{P}_{60}+\mathrm{N}_{120} ; 3-\mathrm{K}_{60}+\mathrm{N}_{120} ; 4-\mathrm{P}_{60} \mathrm{~K}_{60}$ - basic fertilization; 5 - basic fertilization $+\mathrm{N}_{120} ; 6$ - basic fertilization $+\mathrm{N}_{60}+\mathrm{N}_{60} ; 7$ - basic fertilization $+\mathrm{N}_{60} \mathrm{~S}_{70}+\mathrm{N}_{60}$.

Thus, it was established that the highest sowing quality of spelt grain was achieved after 30 - to 180-day storage. Longer storage decreased the germination energy by $1-2 \%$ and laboratory germinability by $15-18 \%$, depending on the type, doses and timing of nitrogen fertilization.

Conclusions. The germination energy of spelt grain was found to be the highest after 30- to 180-day storage (96-99\%). This indicator was most affected by nitrogen fertilizers. After 360-day storage, the germination energy reduced to $87-91 \%$ depending on the type and timing of nitrogen fertilization. The laboratory germinability of spelt grain of $97-99 \%$ maintained from harvesting to storage day 180 . When spelt grain was stored in sealed containers without temperature control, this indicator gradually decreased to $81-84 \%$ for 360 days of storage, depending on fertilizers.

\section{Список використаних джерел}

1. Рябовол Л.О., Кисельова М.І., Любич В.В., Полянецька І.О., Рябовол Я.С. Формування врожайності та вмісту білка в зерні спельтоподібдних гібридів $\mathrm{F}_{3-5}$, одержаних гібридизацією Triticum aestivum L. / Triticum spelta L. Селекųiя i насінництво. 2017. Вип. 111. C. 107-114.

2. Осокіна Н.М., Любич В.В., Возіян В.В., Петренко В.В. Борошномельні показники якості зерна спельти залежно від сорту. Вісник ЖНАЕУ. 2015. № 2(50). Т. 1. С. 296-305.

3. Господаренко Г.М., Любич В.В., Новіков В.В., Желєзна В.В. Білково-протеїназний комплекс зерна сортів пшениці спельти залежно від удобрення. Збірник наукових праць Уманського НУС. 2018. Вип. 1. С. 8-22. DOI 10.31395/2415-8240-2019-94-1-8-16.

4. Кирпа М.Я., Скотар С.О., Базілєва Ю.С., Лупітько О.І. Посівні якості насіння зернових культур та методи їх визначення. Селекція і насіннищтво. 2016. Випуск 110. С. 171-179.

5. Строна И.Г. Общее семеноводство полевых культур. Москва: Колос, 1966. 464 с.

6. Макрушин М.М., Макрушина Є.М. Насінництво (методологія, теорія, практика): підруч., 2-е вид. доп. і перероб. Сімферополь: ВД АРІАЛ, 2012. 536 с.

7. Шемавньов В.І., Ковалевська Н.І., Мороз В.В. Насінництво польових культур. Дніпропетровськ, 2004. 230 с.

8. Avdeeva V.N. Influence of ozone on germination and germinating energy of winter wheat seeds. Engineering for Rural Development series 17: proceedings 17th International Scientific Conference Engineering for Rural Development, 2018. P. 543-546.

9. Насінництво й насіннєзнавство польових культур. За ред М.М. Гаврилюка. Харків. 2007. $214 \mathrm{c}$.

10. Кирпа М.Я. Зберігання зерна - стан і перспектива розвитку в зв'язку зі збільшенням обсягів виробництва зерна в Україні. Бюл. Ін-ту сіл. госn-ва НАAН України. 2011. № 1. С. 9-14.

11. Закладной Г.А. Зерно: не только произвести, но и сохранить. Защчита и карантин 
растений. 2015. № 10. С. 37-40.

12. Ящук Н.Н. Втрати зерна: причини, наслідки та способи запобігти. Пропозищія. 2011. Вип. 7. С. $60-62$.

13. Ходаницкий В., Ходаницкая О. Полба и спельта: новые перспективы выращивания. Пропозищия. 2017. № 3. С. 84-88.

14. Ненайденко Г.Н., Ильин Л.И. Удобрение и качество зерна. Современные технологии хранения зерна в хозяйствах: учеб. пособие. Воронеж: ФГБОУ ВО Воронежский ГАУ, 2014. $135 \mathrm{c}$.

15. Господаренко Г.Н., Ткаченко И.Ю. Формирование продуктивности пшеницы спельты в зависимости от удобрения на черноземе оподзоленном тяжелосуглинистом. Почвоведение и агрохимия. 2014. № 1(52). С. 226-235.

16. Господаренко Г.М., Любич В.В., Полянецька I.О., Возіян В.В. Хлібопекарські властивості зерна спельти залежно від удобрення. Вісник Уманського нащіонального університету садівниитва. 2015. № 1. С. 11-15.

17. International Seed Testing Assosiation (ISTA). International Rules for Seed Testing, Edition 2011.ISTA - Bassersdorf, Switzerland, 2011.

18. Любич В.В., Войтовська В.І., Климович Н.М., Третьякова С.О. Формування посівних властивостей зерна сорго цукрового залежно від сорту, тривалості зберігання та оброблення регуляторами росту. Вісник Уманського НУС. 2020. № 1. С. 30-37.

19. Подпрятов Г.І., Ящук Н.О. Зміна посівних якостей зерна пшениці озимої різних сортів залежно від його вологості в процесі зберігання. Наукові доповіді НУБіП. 2011. № 4.

\section{References}

1. Ryabovol LO, Kiselyova MI, Lyubich VV, Polyanetska IO, Ryabovol YaS. Formation of yield and protein content in grain of spelled-like hybrids F3-5 obtained by hybridization of Triticum aestivum L. / Triticum spelta L. Sel. Nasinn. 2017; 111: 107-114. DOI:

2. Osokina NM, Lyubich VV, Voziyan VV, Petrenko VV. Flour-grinding indicators of spelled grain quality depending on the variety. Bulletin of ZhNAEU. 2015; 2(50)-1: 296-305.

3. Hospodarenko HM, Liubych VV, Novikov VV, Zheliezna VV. Protein-proteinase complex of grain of spelled wheat varieties depending on fertilizer. Zbirnyk naukovykh prats Umanskogo NUS. 2018; 1: 8-22. DOI 10.31395 / 2415-8240-2019-94-1-8-16.

4. Kyrpa MYa, Skotar SO, Bazilieva YuS, Lupitko OI. Sowing qualities of seeds of grain crops and methods of their determination. Sel. Nasinn. 2016: 110: 171-179. DOI:

5. Strona IG. General seed production of field crops. Moscow: Kolos, 1966. 464 p.

6. Makrushyn MM, Makrushyna YeM. Seed production (methodology, theory, practice). Simferopol: VD ARIAL, 2012. $536 \mathrm{p}$

7. Shemavnov VI, Kovalevska NI, Moroz VV. Seed production of field crops. Dnipropetrovsk. 2004. $230 \mathrm{p}$.

8. Avdeeva VN. Influence of ozone on germination and germinating energy of winter wheat seeds. Proc. of the 17th International Scientific Conference Engineering for Rural Development Engineering for Rural Development, series 17. 2018. P. 543-546.

9. Seed production and seed science of field crops. In: MM Havryliuk, editor. Kharkiv, 2007. 214 p.

10. Kyrpa MYa. Grain storage - the state and prospects of development in connection with the increase in grain production in Ukraine. Buleten Instytutu silskogo hospodarstva. 2011; 1: 9-14.

11. Zakladnoi HA. Grain: not only to produce, but also to save. Zakhyst I karantyn roslyn. 2015; 10: $37-40$.

12. Yashchuk NN. Grain losses: causes, consequences and ways to prevent. Propozytsiia. 2011: 7: $60-62$.

13. Khodanytskyi V, Khodanytskaia O. Polba and spelled: new prospects for cultivation. Propozytsiia. 2017; 3: 84-88.

14. Nenaidenko HN, Ylyn LY. Fertilizer and grain quality. In: Modern technologies of grain storage in farms. Voronezh: Voronezh GAU, 2014. 135 p.

15. Hospodarenko HN, Tkachenko IYu. Formation of productivity of spelled wheat depending on fertilizer on chernozem podzolic heavy loam. Pochvovedenie I agrokhimiia. 2014; 1(52): 226- 
235.

16. Hospodarenko HM, Liubych VV, Polianetska IO, Voziian VV. Baking properties of spelled grain depending on fertilizer. Visnyk Umanskogo NUS. 2015: 1: 11-15.

17. International Seed Testing Assosiation (ISTA). International Rules for Seed Testing, Edition 2011 / ISTA - Bassersdorf, Switzerland, 2011.

18. Lyubich VV, Voitovska VI, Klimovich NM, Tretyakova SO. Formation of sowing properties of sugar sorghum grain depending on the variety, duration of storage and processing by growth regulators. Visnyk Umanskogo NUS. 2020; 1: 30-37.

19. Podpryatov GI, Yashchuk NO. Change in sowing qualities of winter wheat grain of different varieties depending on its humidity during storage. Naukovi dopovidi NUBiP. 2011: 4.

\section{ЛАБОРАТОРНА СХОЖІСТЬ ТА ЕНЕРГІЯ ПРОРОСТАННЯ ЗЕРНА ПШЕНИЦІ СПЕЛЬТИ ЗАЛЕЖНО ВІД УДОБРЕННЯ І ТРИВАЛОСТІ ЗБЕРІГАННЯ}

Любич В. В., Желєзна В. В., Костецька К. В.

Уманський національний університет садівництва

Пшениця спельта є перспективною культурою для переробки, оскільки цінні мікронутрієнти рівномірно розподілені в зернівці, тоді як у сучасних сортів пшениці м'якої вони знаходяться в оболонці, алейроновому шарі та зародку. Білок іiі відрізняється вищим вмістом гліадину та нижчим глютеніну, що робить клейковину слабкою, проте вона краще засвоюється організмом людини.

Мета і задачі дослідження: оцінити схожість та енергію проростання зерна пшениці спельти залежно від виду, доз і строків застосування азотних добрив і тривалості зберігання.

Матеріали і методи. Дослідження проводили у лабораторії «Оцінки якості зерна та зернопродуктів» кафедри технології зберігання i переробки зерна Уманського національного університету садівництва. Вивчали сорт пшениці спельти озимої Європа, ориманий гібридизацією Triticum aestivum L./Triticum spelta L. Для удобрення використовували аміачну селітру, сульфат амонію, суперфосфат гранульований, калій хлористий.

Обговорення результатів. У результаті дослідження встановлено, що до зберігання енергія проростання зерна становила 87-90\% залежно від варіанту удобрення. Застосування азотних добрив істотно підвищувало цей показник порівняно з ділянками без добрив. При зберіганні впродовж 30 і 90 діб енергія проростання була найбільшою і становила 9899 \%. При подальшому зберіганні цей показник істотно зменшувався. Найменшим був за внесення $\mathrm{P}_{60} \mathrm{~K}_{60}$ і становив $95 \%$ при зберіганні впродовж 180 діб, 92 - 270 діб, 87 \% 360 діб.

До зберігання і впродовж зберігання зерна пшениці спельти впродовж 30 й 90 діб цей показник становив $99 \%$ i не змінювався залежно від удобрення. Найменшими показниками лабораторної схожості характеризувалось зберігання зерна впродовж року 81-84 \% залежно від удобрення. Найбільшим цей показник був за внесення $\mathrm{P}_{60}+\mathrm{N}_{120} \mathrm{i}$ становив 84 \%, а найменшим у варіанті без добрив та за внесення $\mathrm{N}_{60} \mathrm{~S}_{70}+\mathrm{N}_{60}$.

Висновки. Встановлено, що енергія проростання пшениці спельти найвища за зберігання впродовж 30-180 діб (96-99 \%). Найбільше на цей показник впливає застосування азотних добрив. Після 360 діб зберігання зерна енергія проростання знижується до 87-91\% залежно від виду і строків застосування азотних добрив. Лабораторна схожість зерна пшениці спельти на рівні 97-99 \% зберігається від збирання врожаю до його зберігання впродовж 180 діб. За умови зберігання зерна пшениці спельти у герметичних умовах без контролювання температури цей показник знижується до 81-84 \% залежно від удобрення після зберігання впродовж 360 діб.

\footnotetext{
Ключові слова: пшеничя спельта, схожість, енергія проростання удобрення, зберігання.
} 


\section{ЛАБОРАТОРНАЯ ВСХОЖЕСТЬ И ЭНЕРГИЯ ПРОРАСТАНИЯ ЗЕРНА ПШЕНИЦЫ СПЕЛЬТЫ В ЗАВИСИМОСТИ ОТ ВАРИАНТА УДОБРЕНИЯ И ПРОДОЛЖИТЕЛЬНОСТИ ХРАНЕНИЯ}

Любич В.В., Железная В.В., Костецкая К.В.

Уманский национальный университет садоводства, Украина

Пшеница спельта является перспективной культурой для переработки, поскольку ценные микронутриенты равномерно распределены в зерновке, тогда как в современных сортов пшеницы мягкой они находятся в оболочке, алейроновом слое и зародыше. Белок ее отличается высоким содержанием глиадина и ниже глютенина, что делает клейковину слабой, однако она лучше усваивается организмом человека.

Цель и задачи исследований. Целью исследования было оценить всхожесть и энергию прорастания зерна пшеницы спельты в зависимости от вида, доз и сроков применения азотных удобрений и продолжительности хранения.

Материал и методика. Исследования проводили в лаборатории «Оценки качества зерна и зернопродуктов» кафедры технологии хранения и переработки зерна Уманского национального университета садоводства. Изучали сорт пшеницы спельты озимой Европа, полученный гибридизацией Triticum aestivum L./T. spelta L. Для удобрения использовали аммиачную селитру, сульфат аммония, суперфосфат гранулированный, калий.

Обсуждение результатов. В результате проведенных исследований установлено, что к хранению энергия прорастания зерна составляла 87-90\% в зависимости от варианта удобрения. Применение азотных удобрений существенно повышало этот показатель. При хранении в течение 30 и 90 суток энергия прорастания была самой большой и составляла 98-99\%. При дальнейшем хранении этот показатель существенно уменьшался. Наименьшим он был за внесение $\mathrm{P}_{60} \mathrm{~K}_{60}$ и составил $95 \%$ при хранении в течение 180 суток, $92-270$ суток, $87 \%-360$ суток.

До хранения и в течение хранения зерна пшеницы спельты в течение 30 и 90 суток этот показатель составлял $99 \%$ и не менялся в зависимости от удобрения. Наименьшими показателями лабораторной всхожести характеризовалось хранения зерна в течение года 81-84 \% в зависимости от удобрения. Наибольшим этот показатель был при внесении $\mathrm{P}_{60}+\mathrm{N}_{120}$ и составил $84 \%$, а наименьшим у варианте без удобрений и при внесении $\mathrm{N}_{60} \mathrm{~S}_{70}$ $+\mathrm{N}_{60}$.

Выводы. Установлено, что энергия прорастания пшеницы спельты самая высокая при хранении в течение 30-180 суток (96-99\%). Больше всего на этот показатель влияет применение азотных удобрений. После 360 суток хранения зерна энергия прорастания снижается до 87-91 \% в зависимости от вида и сроков применения азотных удобрений. Лабораторная всхожесть зерна пшеницы спельты на уровне 97-99 \% сохраняется от сбора урожая до его хранения в течение 180 суток. При хранении зерна пшеницы спельты в герметичных условиях без контроля температуры этот показатель снижается до 81-84 \% в зависимости от удобрения после хранения в течение 360 суток.

Ключевые слова: пшеница спельта, всхожесть, энергия прорастания, удобрения, хранения. 


\section{LABORATORY GERMINABILITY AND GERMINATION ENERGY OF SPELT GRAIN DEPENDING ON FERTILIZATION AND STORAGE}

Liubych VV, Zhelezna VV, Kostetska KV

Uman National University of Horticulture

Spelt is a promising crop for processing, as valuable micronutrients are evenly distributed in its grain, while in modern wheat bread varieties they are concentrated in the hull, aleurone layer and germ. Its proteins contain more gliadins and fewer glutenins, making gluten weak, but better digestible in the human body.

Purpose and objectives: to assess the germinability and germination energy of spelt depending on the types, doses and timing of nitrogen fertilization and storage period.

Materials and methods. The study was conducted in the Laboratory of Evaluation of Grain and Grain Product Quality of the Chair of Grain Storage and Processing Technologies of Uman National University of Horticulture. We studied winter spelt variety Yevropa created by hybridization of Triticum aestivum L. with Triticum spelta L. Fertilizers were ammonium nitrate, ammonium sulfate, granular superphosphate, and potassium chloride.

Results and discussion. The study found that before storage the germination energy of grain was $87-90 \%$ depending on fertilization. Nitrogen fertilizers significantly increased this indicator. When grain was stored for 30 and 90 days, the germination energy was the highest and amounted to $98-99 \%$. Longer storage significantly decreased this parameter. It was the lowest after $\mathrm{P}_{60} \mathrm{~K}_{60}$ application: 95\%, 92\% and 87\% when grain was stored for 180, 270 and 360 days, respectively.

Before and after 30- and 90-days storage of spelt grain, this parameter amounted to $99 \%$ and regardless of fertilizers. The lowest laboratory germinability was observed after 1-year storage of grain (81-84\% depending on fertilizers). This indicator was the highest with $\mathrm{P}_{60}+\mathrm{N}_{120 \text {, }}$ amounting to $84 \%$, and the lowest without fertilizers or with $\mathrm{N}_{60} \mathrm{~S}_{70}+\mathrm{N}_{60}$.

Conclusions. The germination energy of spelt grain was found to be the highest after 30- to 180day storage (96-99\%). This indicator was most affected by nitrogen fertilizers. After 360-day storage, the germination energy reduced to $87-91 \%$ depending on the type and timing of nitrogen fertilization. The laboratory germinability of spelt grain of $97-99 \%$ maintained from harvesting to storage day 180 . When spelt grain was stored in sealed containers without temperature control, this indicator gradually decreased to $81-84 \%$ for 360 days of storage, depending on fertilizers.

Key words: spelt, germinability, germination energy, fertilization, storage. 